\title{
SPECIAL CONTRIBUTION
}

\section{Erika Theron, George Bernard Shaw and Social Action}

\section{Memorial Lecture 31 May 2007 at the University of the Western Cape presented by Professor KJ Collins}

The first public speech I made was a vote of thanks. That was in 1966 to Ruth Smalley, an American Professor of Social Work speaking at Stellenbosch University in honour of the centenary celebrations. The visitor was intended to be Florence Hollis, another academic in Social Work, but Professor Hollis was not available.

As Erika Theron was in charge of the visit, the replacement situation was turned into a great success. Like Langenhoven, "kry sy haar swaar met lekkerkry klaar,"1 she overcame the bad with the good. The Department of Social Work at Stellenbosch celebrated Ruth Smalley as the most important exponent of social casework that anyone could ever hope to meet. Professor Theron thought that I, being Engelssprekend, ${ }^{2}$ could manage the vote of thanks and requested me, an Honours student, to do it. You never refused Erika Theron anything.

I prepared my few words, not writing them down as I thought speaking extempore would be livelier. I then spent the whole of Professor Smalley's talk revising my talk in my head... hearing not one word of what she said. The friend with whom I discussed this previously, who is here this afternoon, Valerie, said afterwards that she had worried that this would happen. After I thanked Professor Smalley, with none of her words in my head... I sat down to a burst of applause. I felt so gratified that it took me some time to realise that the applause was not for me but for her, and that I also should have been applauding.

Now 40 years on I am again speaking for the first time - as a Professor at the University of the Western Cape - again in gratitude at a memorial lecture and again feeling that in agreeing to do so, I am doing what Erika Theron would want. This time, however, maybe I can concentrate on what is being said. Willie Esterhuyse heard about our gathering today and specially wrote an article in Die Burger on Erika Theron under the forbidding heading Moeder van morele verset mother of moral resistance - giving a potted biography, which luckily obviates the need for me to do so; it is here for you to read if you wish.

\section{Action orientation}

I would like focus on Professor Theron's choice of inviting an American caseworker (one who works with individuals) to speak to South African social workers in 1966. Why not a community worker, neighbourhood developer, social philosopher or historian or even a social economist, which is what Erika Theron was trained as? She certainly knew eloquent international speakers, having met them overseas regularly as the elected representative of the South African Joint Universities Council. We couldn't help knowing that she knew them because she was always talking about them in class - Katherine Kendall from the US, Eileen Younghusband from the UK, Maria Kamphuis from Holland.

So what makes me question the choice of Florence Hollis or Ruth Smalley as centenary speaker? Erika Theron was not a caseworker; she was a community developer. She said she couldn't do casework at all. She felt helpless when faced with personal problems. She found the emphasis on

\footnotetext{
${ }^{1}$ She managed to deal with difficult situations ... and even enjoyed doing so.

${ }^{2}$ English speaking.
} 
listening and accepting non-judgmentally alien to her nature. She had to excuse herself whenever it came to the topic. Professor Theron could form no opinions on it; she turned away with a strong body language of aversion. So she happily employed Dr Annette Muller, one of her ex-students, one of her beloved ex-students, to teach this course.

At the same time our curriculum taught us that any effective social work would involve individuals, groups and communities. Our training was generic, not specialist. We learnt that if we could not manage marital conflict, we would have communities of child abuse. If we could not mobilise groups, we would have marginalised individuals, and if we could not identify community issues, we would have unequally resourced groups in society.

Professor Theron chose a caseworker as our celebrity speaker because at last, at last, casework was no longer stopping at merely assessing and understanding human behaviour - "diagnosing" we called it then - but was setting out a theory of intervention: how we were going to "treat" people with problems.

What we knew already about intervention was sparse. The psychosocial literature from Sociology and Psychology spelt out the problems that people experienced in adjustment to an apparently unfeeling society. We studied Felix Biestek's book called The casework relationship. We knew off by heart the ingredients of a relationship that a Catholic priest considered the best foundation for helping clients. Yet we were left with that uncomfortable feeling of insufficiency. How could we actually help a person?

With these new casework theories we could now not only relate well to a person with a problem and describe and explain the problem, but we could change it. "Now we can see our way clear to doing something," Erika Theron said.

We could identify six steps of intervention and apply them in action to "an individual-with-aproblem" or an "individual-in-a-situation", which was the jargon of the time. The enthusiasm for Hollis' six steps was so contagious in the department that we as the Honours students of 1966 suspected that we had to know them for the oral exam. We were right.

\section{Authority figure}

I had one year at University of Cape Town before I decided that all I was doing was travelling to university and back. Perhaps that means that I wasn't meeting enough boyfriends? Had I moved to Stellenbosch in 1960 so that an English-speaking girl might stand out as a rose amongst the thorns? Vaguely in the back of my mind was an impression that improved Afrikaans would be useful in dealing with clients in South Africa, and that the Stellenbosch Social Work course was said to be dynamic.

I was placed in a private student hostel called "Eet 'n Rus", 3 where we ate as we pleased and I was quite prepared to rest as well, rest being a part of the normal university lifestyle I was accustomed to. My second lecture for Social Work I missed comfortably, accustomed to the University of Cape Town style of nobody apparently noticing whether you were present or not. The third lecture I was back there only to be asked by Professor Erika Theron - short and sturdy, upright, smartly dressed, not a curly grey hair out of place, piercing brown eyes fixed on me, in her deep slightly harsh voice - "Oh yes, Miss Farber, we welcome you back in class and are interested in knowing about your whereabouts yesterday”. I had to answer in Afrikaans in front of

\footnotetext{
3 "Eat 'n Rest".
} 
45 students who were strangers, some of whom are here this afternoon. They will remember my $\mathrm{krom}^{4}$ Afrikaans.

From then onwards the whole class knew that there was no chance of being absent. When I was subpoenaed to court in third year as a witness, having been the passenger in a serious motor accident, I told the sheriff that I would not be allowed to miss a class. The court session would have to wait until university vac. He then instructed me that Professor Erika Theron was not the ultimate authority in the Western Cape. It was difficult to believe that.

Stellenbosch was full of students on pedal bikes in the 1960s. I had one too. This was quite adequate for me. My two best friends, both here this afternoon, Jill and Kathy, had mopeds. Whenever I was out with one of them on the roads, they became impatient with my slowness. So we would keep one hand on the bicycle handlebar and hold on to each other's hand. Their bikes' power would pull mine along. When they changed gears, they would let go of me. I would pedal madly to keep up as they stretched out a hand again and on we would go.

We would travel next to each other at $40 \mathrm{~km}$ per hour instead of singe file at $15 \mathrm{~km}$ per hour. Great fun, but of course dangerous and in complete defiance of traffic bylaws. I don't think my mother, here this afternoon, has heard this story. My young brother is also here, but their reactions will be very different. The traffic authorities never caught us at it. But who did?

Every single time I was travelling trailer style, Professor Erika Theron's car would sweep around a corner in front of us or pass by on the other side of the road. I always hoped she had not seen us but, sure enough, every next class there would be a comment - "There are some among us who disregard the rules of the road without the least consideration for the safety of others" - in her elevated Afrikaans with a neutral tone of voice and no expression on her face. This to a student who was learning about the dignity and worth of the individual and principles of social justice in communal life.

\section{Distance and identity}

At our university class reunion 40 years on in 2002, 16 of us sat at breakfast after church in the Stellenbosch Botanical Gardens and reminisced. Each took a turn to tell a story from our student days involving Erika Theron. Every single story reflected awe. The one I remember best was by Japie van der Merwe, here this afternoon, who told of being away on a two-day study tour with the lecturers visiting plattelandse ${ }^{5}$ organisations. Terrifying enough to sit at table and make light conversation over dinner but then came, "Mnr van der Merwe, as die enigste man hier"- I remind you that it was the 60s, where gender roles were more clearly distinguished in terms of tasks than they are now - "wat gaan ons drink?" in that cool voice. He said, "Nee dr, ek is nie dors nie, maar hier is water." And he offered the carafe of water. She said, "Nee, ons gaan wyn drink." " Japie can't recall who eventually ordered the wine. To this day, he feels embarrassed by his naivety.

You will correctly conclude that we as students were not merely in awe of Erika Theron; actually we were very-scared of her. Yet we identified unstintingly with her values.

\footnotetext{
${ }^{4}$ Lit. "skew".

${ }^{5}$ Rural.

6 "Mr van der Merwe, as the only man here ... what are we going to drink?"

"No, Doctor, I'm not thirsty, but here is water".

"No, we are going to drink wine".
} 
Perhaps at this point you are wondering: what is Kathleen Collins talking about? How could a person who inspired such fear be not only a wonderful role model, but inspire us to feel that we also could be wonderful too. In our own ways, not in hers?

I shall answer this by relating to literature and leaving you the listener to deduce your own meanings from the following metaphors. Deliberately using this device in my lecture, namely asking the recipient to take responsibility for drawing her or his own conclusions, you will realize that I am applying the sound teaching and learning methods that the University of the Western Cape espouses.

\section{PP Metaphors in literature}

Henry James writes in Portrait of a Lady in 1880 of the many aspects of procurement. There are two characters who were collectors of objects d'art. One, Osmond Gilbert, eventually marries the Lady of the title - Isabel. And in the novel we have to work out why it is that the worst man gets the best woman, leading to a hollow life. Another character is Mr Touchett, Isabel's uncle. [READINGS.] What we are busy looking at here is that with Gilbert Osmond the appearance takes precedence over reality. For him and his type the veneer matters more than the substance. This is very convincing. In the plot of the novel, extrinsic qualities more than intrinsic hold sway to the detriment of Isabel's life and those who love her as well as Gilbert himself.

Moving on with this same symbol of tension between appearance and reality, aesthetics and ethics, we consider an extract from Sonder Hoed of Handskoen, ${ }^{7}$ Erika Theron's autobiography. Why such an unassuming yet abstruse title? On Monday mornings we used to hear expostulations about the jong dames ${ }^{8}$, and that meant students, maybe Social Work students, whom Dr Erika had yesterday watched in church, dressed up in flowing garments, hats and gloves to the extent that these beautiful creatures belonged at a garden party, not in church. Obviously the last thought on their minds was divinity; basically they were being narcissistic. They had lost sight of the primary aim of going to church. She intended never to lose sight of her primary aim, hence Sonder Hoed of Handskoen.

In the extract I have chosen for you, Erika Theron describes an incident where she faced a busy Buitenkant Street in Cape Town and became aware of a small figure, 'n verslenterde bruin seuntjie, a ragamuffin - now we would call him a street-child - a few metres away jumping up and down. She said to herself - he will be run over. She moved along and said to him - "We must cross the road together." She stretched out her hand which he grasped firmly. There came a pause in the traffic; he pulled her hand and they then jaywalked across. Reaching the other side, he grinned broadly at her, let go and sped up the hill to District 6. Then she realized - "This brown child thought that I needed his help and that he was escorting me safely across the road." She entitles the extract: Take each other's hand (Theron, 1983). In it, both people easily took to the role of helper. Conversely, neither of them, not the elderly person nor the child, felt at all in need of help. Does it matter that there was this lack of reciprocity in the feeling underlying the interaction? They crossed the road more aware and more alert than they would have done alone. They enjoyed their participation in the experience; their sense of helping, their pleasure in each other's reaction. They reached their aim together. The outcome was excellent. The incident provides an everlasting symbol of hidden meaning.

\footnotetext{
${ }^{7}$ Without Hat or Gloves.

${ }^{8}$ Young ladies.
} 
Now we come to George Bernard Shaw. Born in Dublin in 1856, he followed his mother in her musical career to London and spent years in the Reading Room of the British Museum, discovered Karl Marx and joined the Fabian Society as a socialist. First known as a critic, he was very outspoken and sardonic, including in his criticism of music, for example:

"Miss Osmond, who appeared in Steinway Hall on the $16^{\text {th }}$ is a young English pianist who has studied in England from first to last, which is at present, I am sorry to say, a course rather patriotic than wise." (The World, 24 Feb 1892)

He then achieved fame as a playwright and was considered equal to Winston Churchill in popularity in Britain in the first half of the $20^{\text {th }}$ century. The pointed witticisms never stopped. In 1926 the Stratford Theatre was burned down and among the messages of condolence, Shaw in a dissenting tone told a reporter "Stratford on Avon is to be congratulated on the fire," because a modern theatre for performing Shakespeare was needed. He died at the age of 94 after falling while pruning an apple tree; he had aroused the admiration of even those who had not appreciated his writing (Brown, 1970).

Shaw thought that he had solved all the social problems by reframing them in his plays. He was disappointed that his solutions were not adopted by the social reformists of the day.

Erika Theron did not think she had solved all social problems, but she aimed to change some of them. She lobbied to abolish the Group Areas Act, the Immorality Act and the Prohibition on Mixed Marriages Act with logic and research as her backbone. In her recommendations in the Coloured Affairs Commission in 1976, she spoke of the only differences between brown and white people being geographical, and stated that full participation between communities should be adopted; in other words, she was recommending dismantling apartheid because of its effects on human productivity and social relations.

She was disappointed at the slow executive response to her Commission's report (166 recommendations out of 220 decisions were accepted, but the implementations got stuck) and then wrote another more reader-friendly report on the topic for general consumption. She continued to conscientise the reading public and all her committees. Subsequently, in 1981 PW Botha turned on her publicly when he said he was "siek en sat vir haar nonsense," whereupon there was strong reaction. The Cape Argus, to offer one example, wrote that the Prime Minister was unwell, appropriately so, as this was his own rank and file wanting his laws overturned. Yet we had to wait for another 10 years to see the beginnings of real change in racial laws. She was at least able to see those beginnings before she died in 1990, but by then she was "siek en sat" herself of bureaucratic mangling and the wrong people in charge "- halwe mannetjies op wie se skouers groot verantwoordelikhede rus" ${ }^{10}$ (Theron, 1983:68). Nowhere was there the man for the job.

In Major Barbara Shaw is concerned about the subject of religious belief as it affects human conduct. This was the play we heard about in Erika Theron's classes ad infinitum. Every time she paid a visit to the Minister in Parliament, she spoke about the visit to Lady Britomart's posh home. Every time there was a reference to welfare organisations' drive for money, we heard about Undershaft and his millions. Every time she spoke about the dependence of the poor, we heard about Bill Walker placing money above soul. Was this boring? Not to me, because every extract that we came to was approached as if afresh. The character after whom the play is named,

\footnotetext{
9 "I am sick and tired of her nonsense".

10 “ - little half-men on whose shoulders rest great responsibilities".
} 
Major Barbara, did social work in the Salvation Army. She was a strong character with a great influence on the poor who come to her. She was also a rebel against her wealthy background and against her father Undershaft, who runs a successful foundry in a model town, making gunpowder. The crux of the play is the confrontation of viewpoints, a contest between Barbara and her father, the one on the side of God, the other echoing Shaw's view as presented in the Preface, that salvation must come to us solely because of our own efforts. I quote from Act One:

UNDERSHAFT: Well I will make a bargain with you. If I go to see you tomorrow in your Salvation Shelter, will you come the day after to see me in my cannon works?

BARBARA: Take care. It may end in your giving up the cannons for the sake of the Salvation Army.

UNDERSHAFT: Are you sure it will not end in your giving up the Salvation Army for the sake of the cannons?

Barbara refuses money which her father offers, calling it tainted. Undershaft tells her that his religion is being a millionaire.

BARBARA: You're not a millionaire are you, Peter? [one of the shelterers]

PETER: No and proud of it.

UNDERSHAFT: (gravely) Poverty, my friend, is not a thing to be proud of.

PETER: (angrily) Who made your millions for you? Me and my like. What's kept us poor? Keeping you rich. I wouldn't have your conscience, not for all your income.

UNDERSHAFT: I wouldn't have your income, not for all your conscience, Mr Shirley.

Barbara has a fiancée, Cusins, in the Army who, although working as a committed Christian alongside her, is attracted by her father's ideas and eventually takes over the business from him. What fascinates him about the Salvation Army are its qualities "of joy, of love, of courage, ...it marches to fight the devil with trumpet and drum, with music and dancing, with banner and palm, as becomes a sally from heaven by its happy garrison." Undershaft charges him with readiness to convert the Salvation Army to the worship of Dionysos and he says: "The business of the Salvation Army is to save, not to wrangle about the name of the pathfinder, Dionysos or another: what does it matter?"

So Barbara has to watch her fiancée apparently desert her. She has to witness in even more horror, a trusted colleague negotiate a cheque from her father for five thousand pounds to keep the shelter open for her prospective converts. She has to hear him say that money is seen to be of greater value than souls. Barbara is so disillusioned that she discards her Salvation Army uniform, whereas her colleague who accepts the cheque based on bloodshed and slaughter says: "The longer I live the more proof I see that there is an Infinite Goodness that turns everything to the work of salvation sooner or later." By now Barbara is so alienated from her faith that she feels that she may never pray again.

However, these orientations all swing around to work together in Act 111. Keeping his Christian ideals, Cusins becomes determined to use his newly gained power of ownership of a gunpowder business to make war on war. Barbara moves on; she realizes that she must look for her work of salvation everywhere and says: "There is no wicked side; life is all one."

We wonder how she has come to terms with this difference from her early dogmatism. The play ends with the themes of religion and social reform closely connected. Barbara indicates that people are put on the earth to be useful and she recognises that her father was right when he 
challenged her to try to save his well-fed workers. He speaks of the seven deadly sins: "Food, clothing, firing, rent, taxes, respectability and children. Nothing can lift those seven millstones from Man's neck but money, and the spirit cannot soar until the millstones are lifted."

The end of the play seems unresolved. The irony of Barbara's acceptance of blood money to save souls and her pragmatism that money precedes faith in divinity is not entirely convincing, given her previous disillusionment, which is most convincing. Could she now really believe that souls are hungry only when bodies are full? Undershaft's point is that until the visionaries or Professors of Greek, that is academics and poets, are ready to soil their hands with practical matters, the world will be controlled by those who resist their benevolent impulses and who concentrate on worldly affairs. Shaw was not opposed to religious thought in the paradoxes he presents to us and that Dr Erika fastened on with glee. The audience of the play and the audience present today might ask: how ready are individuals to continue their hard work, holding opposing viewpoints, to meet one another? And is Barbara happy with herself? This is not answered by GBS and was not answered by Erika Theron either.

What happened in the class is that we were left to solve these dilemmas ourselves. And we are continuing to wrestle with dilemmas like these. Long may it last.

\section{At a loss for words}

On the last day of our BA class in October 1962, we students waited as usual for ET's footsteps outside the door. There they were, steady as ever. We fell silent as usual, in she came but instead of her normal controlled demeanour, march to the podium and greeting "Môre klas," she stood stock still. I watched her eyes move quickly from one person to another. She was trying to absorb the picture. We were all dressed up as social problems. There was the battered wife, the neglected child, the alcoholic, the deserted rural family, the physically disabled, the unmarried mother, the derelict aged person, poverty in all its dramatic guises. We had planned this event carefully and taken trouble in choosing our clothes and accoutrements. She stared at us, the silence grew long, we started laughing awkwardly and then she disappeared. We stayed behind waiting nervously. Once before she had walked out of class, but the reason then was plain - we had not prepared our reading. That time we had sent a deputation upstairs to apologise. This time we did not know what to do. Then she reappeared with all the staff in tow. They were there to admire us. One by one we said what we represented; Dr Erika said nothing. But at the farewell dinner that she provided for every final-year class, she read us a long poem, recalling each one of us and our social problem.

\section{Forms of knowledge}

Having said earlier that I wanted you to come to your own conclusions about my images, I have decided to give you some help from a writer on participatory research whom I find useful. Peter Park in the late 1990s describes three forms of knowledge (Park, 1997).

- The first is representational, that is factual knowledge, the kind of knowledge that provides reasons and where we have to describe our observations carefully and with evidence, like what makes this event comfortable for you - the temperature suited to human body requirements, the seating equally so, requiring concentration from you for 40 minutes as a normal concentration span, the anticipation of interaction with others with common interests as social beings and other objective points we could measure.

- Then there is reflective knowledge, which relates to human values in which questions of right and wrong, good and bad are raised This form of knowledge is sometimes called critical consciousness. Your choice of being here this afternoon reflects your sense of the place where 
you ought to be, rather than anywhere else you could have chosen - in front of a computer, in the library or on a sports field. Reflective knowledge is the basis of social change. Not to be measured, it can only be subjectively described.

- Lastly, relational knowledge is the understanding we have of others as human beings and partners. It is the experience of being familiar with someone, felt directly and emotively. Shared moments of life give us relational knowledge. The only reason for many of you being here this afternoon is the shared experience that we have with one another. It has made all the difference to me to have people here who went through what I did, with me, who know me. This relational knowledge is often the only foundation for great human challenge and endeavour.

Going back again to the three forms, representational knowledge we know well; it forms the logical framework for all experiments in natural science and some in social science and has been documented since history began $6^{\text {th }}$ century BC. Reflective knowledge has been expressly included in scientific reports for the last 50 years, after we realised that we had to explain where people were coming from in order to get them to work together. But relational knowledge receives scant attention in scientific literature. It is time to change this. Things are not what they seem.

I would like to end with this quotation.

The sun never says to the earth,

"You owe me." Look what happens

with a love like that.

It lights the whole world. (Hafiz)

\section{REFERENCES}

BROWN, G.E. 1970. Literature in perspective: George Bernard Shaw. London: Evans Brothers.

JAMES, H. 1976. Portrait of a lady. Fairfield NJ: Augustus M. Kelly.

PARK, P. 1997. Participatory research, democracy and community. Practicing Anthropology, 19(3):8-13.

SHAW, G.B. 1946. Major Barbara. Harmondsworth, UK: Penguin Books.

THERON, E. 1983. Sonder hoed of handskoen. Cape Town: Tafelberg. 